\title{
Composition, quality and oxidative stability of virgin olive oils from some selected wild olives (Olea europaea L. subsp. Oleaster)
}

\author{
By Bechir Baccouri, Wissem Zarrouk, Olfa Baccouri, Mokhtar Guerfel, Issam Nouairi, \\ Douha Krichene, Douja Daoud and Mokhtar Zarrouk*
}

\author{
Laboratoire Caractérisation et Qualité de l'Huile d'Olive, Centre de Biotechnologie, \\ Technopole de Borj Cedria, BP 901, 2050, Hammam-Lif, Tunisia.
}

${ }^{*}$ Corresponding author: e-mail: mokhtar.zarrouk@ cbbc.rnrt.tn

\section{RESUMEN}

Composición, calidad y estabilidad oxidativa de aceite de oliva virgen procedente de algunas variedades salvajes seleccionadas de aceitunas (Olea europaea L. subsp. Oleaster).

En este trabajo se han caracterizado los aceites obtenidos a partir de siete acebuches previamente seleccionados entre varias poblaciones de Olea europea L. Subsp. Oleaster. El estudio se llevó a cabo durante las campañas de producción $2003 / 04,2004 / 05$ y 2005/06. Varios parámetros analíticos fueron evaluados: composiciones en ácidos grasos, pigmentos, tocoferoles, fenoles; así mismo, se investigó la relación de estos parámetros con la estabilidad de los aceites.

Los resultados obtenidos mostraron que todas las muestras de frutos de acebuche produjeron aceites cuya composición de ácidos grasos, tocoferoles y compuestos fenólicos cumplió las normas comerciales para aceite de oliva virgen del Comité Oleícola Internacional.

El análisis de los tocoferoles con el HPLC reveló la presencia de las formas $\alpha, \beta, \gamma$ y $\delta$ en todos los aceites de oliva estudiados. El contenido total de tocoferoles estuvo claramente influido por la variedad, oscilando entre $310 \mathrm{mg} / \mathrm{kg}$ en SB12 hasta $780 \mathrm{mg} / \mathrm{kg}$ en H3. La forma $\alpha$ de los tocoferoles fue la más importante mientras que de las formas $\beta, \gamma$ y $\delta$ se hallaron menores contenidos. Los resultados indicaron una clara influencia de los fenoles y de los $o$-difenoles en la estabilidad de los aceites vírgenes de oliva $\left(R=0.905,0.963\right.$ con $P<10^{-3}$, respectivamente), y una contribución mucho más baja de los tocoferoles $(R=0.568)$ y de los ácidos grasos $(R=0,563)$.

PALABRAS CLAVE: Acebuche - Aceite de oliva virgen Estabilidad - Fenoles - Tocoferoles.

\section{SUMMARY}

Composition, quality and oxidative stability of virgin olive oils from some selected wild olives (Olea europaea L. subsp. Oleaster).

A study on the characterization of virgin olive oils from wild olives (Olea europaea L. subsp. Oleaster) was conducted in order to define new cultivars which are welladapted to the Tunisian environment and yield high quality oils. The study was done during the crop years 2003/04, $2004 / 05$ and 2005/06. The main analytical parameters of the oils were evaluated: fatty acid compositions, chlorophylls, carotenoids, tocopherols and phenolic compounds as well as their relationship with oxidative stability.

The fatty acid composition of all the wild olive trees tested produced virgin olive oil which complies with commercial standards, as well as for their appreciable amounts of tocopherols and phenolic compounds. Tocopherol analysis by HPLC revealed the presence of $\alpha, \beta, \gamma$ and $\delta$ tocopherols in all the studied olive oils. Total tocopherol content was significantly influenced by the varietal factor. It ranged from 310 (SB12) to $780 \mathrm{mg} / \mathrm{kg}(\mathrm{H} 3)$. As for total tocopherols, the amount of each tocopherol varied according to genotype. $\alpha$ tocopherol is the most prominent, whereas $\beta, \gamma$ and $\delta$ tocopherols are less represented. Results showed a clear influence of total phenols and 0 -diphenols on virgin olive oil stability $\left(R=0.905,0.963 P<10^{-3}\right.$, respectively), and a much lower contribution of tocopherols $(R=0.568)$ and acidic composition $(R=0,563)$.

KEY-WORDS: Oxidative stability - Phenols - Tocopherols - Virgin olive oil - Wild olive.

\section{INTRODUCTION}

The olive tree (Olea europaea L.) is a subtropical species typical of the Mediterranean basin where it represents the most important oilproducing crop. Virgin olive oil, due to its use without refining, shows very interesting nutritional and sensorial properties, being one of the pillars of the so-called Mediterranean diet. Its oxidative stability, sensory quality and health properties stem from a prominent and well-balanced chemical composition (Boskou, 1996; Servilli et al., 2004).

The increasing popularity of olive oil has been mainly attributed to its high content of oleic acid, which may affect the plasma lipid/lipoprotein profiles and its richness in phenolic compounds acting as natural antioxidants, which may contribute to the prevention of human disease (Visioli et al., 1998; Visioli et al., 2000).

Tunisia occupies the fourth place on a worldwide scale in terms of olive oil production (IOOC, 2004). Tunisian olive plantations are spread all over the country in different edapho-climatic conditions and account for about 63 million trees covering 1.6 million hectares. A major effort has been made recently for improving the quality of olive oil produced in Tunisia.

At present the Tunisian olive grove is dominated by only two main varieties: Chétoui and Chémlali. The introduction of different virgin olive oil types into the market, with different sensory and chemical 
characteristics is the main interest. Therefore, the identification and evaluation of wild olive trees allowed us to recognize Tunisian grove richness and diversity in order to select new olive varieties, adapted to environmental conditions and arid climate and to diversify the genetic resources (Zohary, 1994; Trigui, 1996; Sedgley and Wirthensohn 2000).

Although the study was carried out in Tunisia, the methodology might be applied to other countries with wild olive trees, in order to contrast productivity and oil quality with those resulting from native cultivars and transplanted foreign varieties.

\section{MATERIAL AND METHODS}

\subsection{Plant material}

Seven wild olive trees were selected after agronomic and chemical evaluations among wild olive populations originating from different regions of Tunisia (Mateur, Ichkeul, Enfidha, Grombalia, Sers and Neber) totalling 150 trees. The selected wild olives were kept in the Experimental Station of Tunis Biotechnology Center; under the same pedoclimatic conditions. Olive fruits were picked at the same stage of ripeness, and their oils were extracted with the same processing system. Olives were hand picked in triplicate in perfect sanitary conditions.

\subsection{Oil sample extraction}

The same laboratory mill was used to prepare the olive oil samples. Using an Abencor analyzer (MC2 Ingenierias y Sistemas, Sevilla, Spain), 1.5-2 kg of olives were crushed with a hammer mill and slowly mixed for $30 \mathrm{~min}$. The resulting paste was centrifuged in thin layer for oil extraction. The oil was separated by decanting, transferred into dark glass bottles, and stored in the dark at $4^{\circ} \mathrm{C}$.

\subsection{Fatty acid composition}

The determination of fatty acid composition was carried out according to European regulations (EEC 2568/91). Briefly, the methyl-esters were prepared by vigorous shaking of a solution of the oil in hexane (0.2 $\mathrm{g}$ in $3 \mathrm{ml}$ ) with $0.4 \mathrm{ml}$ of $2 \mathrm{~N}$ methanolic potassium hydroxide and analyzed by gas chromatography. A gas chromathograph, fitted with a FID detector, was employed. A fused-silica capillary column (30 m x $0.25 \mathrm{~mm}$ i.d. $x 0.25 \mu \mathrm{m}$ film thickness), was used. The carrier gas was nitrogen, at a flow through the column of $1 \mathrm{ml} \mathrm{min}{ }^{-1}$. The injector and detector temperatures were kept at $240^{\circ} \mathrm{C}$ and $260^{\circ} \mathrm{C}$, respectively; and the oven temperature at $210^{\circ} \mathrm{C}$. Injection volume of $1 \mu \mathrm{l}$ was used.

\subsection{Total phenol content determination}

Total phenols and o-diphenols amounts were quantified colorimetrically. Phenolic compounds were isolated by triple extraction of a solution of oil in hexane with a water-methanol mixture (60:40, $\mathrm{v} / \mathrm{v}$ ). The Folin-Ciocalteau reagent (Merck) was added to a suitable aliquot of the combined extracts, and the absorption of the solution at $725 \mathrm{~nm}$ was measured. Ortho-diphenols were measured colorimetrically at $370 \mathrm{~nm}$ after adding $5 \%$ (wt/vol) sodium molybdate in $50 \%$ ethanol to the extract. Values are given as milligrams of caffeic acid per kilogram of oil (Vazquez et al., 1973).

\subsection{HPLC analysis of tocopherols}

One gram of oil sample was dissolved in $10 \mathrm{~mL}$ of $n$-hexane, extracts were filtered through a $0.45 \mu \mathrm{m}$ nylon filter. $\alpha-, \beta$ - and $\gamma$-tocopherols ( $\alpha$-toc, $\beta$-toc, and $\gamma$-toc, respectively) were determined by HPLC (HP1100), equipped with a photodiode detector array set at $295 \mathrm{~nm}$. The column used was a HPPhenomenex, Luna, CN 100A, (150 mm, $4.6 \mathrm{~mm}$ ID) in isocratic conditions with $n$-hexane: dichloromethane $(95.5 ; \mathrm{v} / \mathrm{v})$ as the mobile phase at a flow rate of $1 \mathrm{~mL}$ $\mathrm{min}^{-1}$. The injection volume was $20 \mu \mathrm{L}$. Analyses were carried out at room temperature. The total run time was $10 \mathrm{~min}$. Three calibration curves were constructed with standard solutions of each compound $\left(\alpha-, \beta\right.$ - and $\gamma$-toc, $r^{2}=0.999, r^{2}=0.986$, and $r^{2}=0.999$ ) and used for quantification. Results are given as milligrams of tocopherol per kilogram of oil (IUPAC, 1992).

\subsection{Rancimat assay}

Oxidative stability was evaluated by the Rancimat method (Gutierrez, 1989). Stability was expressed as the oxidation induction time (h), measured with the Rancimat 743 apparatus (Metrohm $\Omega$ ), using an oil sample of $3.6 \mathrm{~g}$ warmed to $101.6^{\circ} \mathrm{C}$ and an air flow of $10 \mathrm{~L} / \mathrm{h}$.

\subsection{Statistical analysis}

The results are reported as the mean values $(n=9)$. In addition, Duncan's multiple range tests were used to determine significant differences among data. Statistical analysis was performed using the Statistica 5.0 package (StatSoft '97edition).

\section{RESULTS AND DISCUSSION}

\subsection{Chemical composition}

\subsubsection{Fatty acid determination}

The distribution of fatty acids, from all tested samples, covered the normal range expected for olive oil according to the International Olive Oil Council trade standars (IOOC, 2004) (Table 1). The major fatty acids were oleic, palmitic, linoleic, stearic and palmitoleic. Oleic acid is the main monounsaturated fatty acid, with high levels (71.1- 
Table 1

Fatty acid composition (\% of total fatty acids) of olive oils

\begin{tabular}{|c|c|c|c|c|c|c|c|}
\hline Wild trees & $\begin{array}{l}\text { Palmitic acid } \\
\text { (C16:0) }\end{array}$ & $\begin{array}{l}\text { Stearic acid } \\
\text { (C18:0) }\end{array}$ & $\begin{array}{l}\text { Arachidic acid } \\
\text { (C20:0) }\end{array}$ & $\begin{array}{l}\text { Oleic acid } \\
\text { (C18:1) }\end{array}$ & $\begin{array}{c}\text { Palmitoleic acid } \\
\text { (C16:1) }\end{array}$ & $\begin{array}{l}\text { Linoleic acid } \\
\text { (C18:2) }\end{array}$ & $\begin{array}{l}\text { Linolenic acid } \\
\text { (C18:3) }\end{array}$ \\
\hline $\mathrm{H} 3$ & $11.1^{\mathrm{bc}}$ & $2.1^{\text {cd }}$ & $0.47^{\mathrm{a}}$ & $76.8^{\mathrm{ab}}$ & $0.5^{d}$ & $6.8^{\mathrm{e}}$ & $0.65^{a b}$ \\
\hline $\mathrm{ZI2}$ & $8.7^{c}$ & $3.0^{\mathrm{ab}}$ & $0.5^{\mathrm{a}}$ & $78.4^{\mathrm{a}}$ & $0.4^{d}$ & $7.1^{\mathrm{e}}$ & $0.7^{\mathrm{ab}}$ \\
\hline $\mathrm{ZI1}$ & $9.2^{\mathrm{bc}}$ & $3.5^{\mathrm{a}}$ & $0.5^{\mathrm{a}}$ & $74.8^{\mathrm{bc}}$ & $0.6^{d}$ & $10^{d}$ & $0.8^{\mathrm{a}}$ \\
\hline MAT22 & $11.9^{b}$ & $2.2^{\text {cd }}$ & $0.4^{\mathrm{ab}}$ & $71.1^{d}$ & $0.6^{d}$ & $12.4^{\mathrm{bc}}$ & $0.72^{\mathrm{ab}}$ \\
\hline MAT7 & $10.6^{\mathrm{bc}}$ & $1.5^{\mathrm{d}}$ & $0.3^{\mathrm{b}}$ & $71.1^{d}$ & $1.1^{\mathrm{b}}$ & $14.2^{\mathrm{b}}$ & $0.6^{\mathrm{ab}}$ \\
\hline MAT10 & $8.7^{\mathrm{c}}$ & $2.3^{\mathrm{bc}}$ & $0.4^{\mathrm{ab}}$ & $74.6^{c}$ & $0.5^{d}$ & $11.6^{\mathrm{cd}}$ & $0.7^{\mathrm{a}}$ \\
\hline SB12 & $10.5^{\mathrm{bc}}$ & $2.2^{\text {bcd }}$ & $0.4^{\mathrm{a}}$ & $71.4^{d}$ & $0.9^{c}$ & $13.6^{\mathrm{bc}}$ & $0.4^{\mathrm{b}}$ \\
\hline
\end{tabular}

Significant differences in the same row are shown by different letters $(P \leq 0.001)$.

Table 2

Total and individual tocopherol levels in virgin olive oil

\begin{tabular}{cccccc}
\hline Wild trees & $\begin{array}{c}\text { Total tocopherols } \\
(\mathbf{m g} / \mathbf{k g})\end{array}$ & $\begin{array}{c}\boldsymbol{\alpha} \text { tocopherols } \\
(\mathbf{m g} / \mathbf{k g})\end{array}$ & $\begin{array}{c}\boldsymbol{\beta} \text { tocopherols } \\
(\mathbf{m g} / \mathbf{k g})\end{array}$ & $\begin{array}{c}\boldsymbol{\gamma} \text { tocopherols } \\
(\mathbf{m g} / \mathbf{k g})\end{array}$ & $\begin{array}{c}\boldsymbol{\delta} \text { tocopherols } \\
(\mathbf{m g} / \mathbf{k g})\end{array}$ \\
\hline H3 & $781.8^{\mathrm{a}}$ & $590.0^{\mathrm{a}}$ & $68.0^{\mathrm{a}}$ & $98.3^{\mathrm{a}}$ & $25.6^{\mathrm{c}}$ \\
ZI2 & $586.3^{\mathrm{b}}$ & $427.0^{\mathrm{b}}$ & $59.0^{\mathrm{b}}$ & $66.7^{\mathrm{cd}}$ & $34.1^{\mathrm{a}}$ \\
ZI1 & $518.8^{\mathrm{c}}$ & $367.0^{\mathrm{c}}$ & $49.4^{\mathrm{c}}$ & $75.6^{\mathrm{bc}}$ & $26.9^{\mathrm{bc}}$ \\
MAT22 & $350.5^{\mathrm{d}}$ & $208.0^{\mathrm{d}}$ & $52.2^{\mathrm{ab}}$ & $58.1^{\mathrm{d}}$ & $33.1^{\mathrm{ab}}$ \\
MAT7 & $523.2^{\mathrm{c}}$ & $362.0^{\mathrm{c}}$ & $47.0^{\mathrm{c}}$ & $82.0^{\mathrm{b}}$ & $33.1^{\mathrm{ab}}$ \\
MAT10 & $482^{\mathrm{c}}$ & $334.0^{\mathrm{c}}$ & $48.2^{\mathrm{c}}$ & $71.1^{\mathrm{c}}$ & $29.6^{\mathrm{abc}}$ \\
SB12 & $309.5^{\mathrm{d}}$ & $170.0^{\mathrm{d}}$ & $46.1^{\mathrm{c}}$ & $67.8^{\mathrm{cd}}$ & $25.5^{\mathrm{c}}$ \\
\hline
\end{tabular}

Significant differences in the same row are shown by different letters $(P \leq 0.001)$.

$78.4 \%$ ) according to genotypes. Palmitic acid, the major saturated fatty acid, ranged from 8.7 to $11.9 \%$, whereas, linoleic acid was the dominant polyunsaturated fatty acid, ranging from 6.8 to $14.2 \%$. Another important saturated acid was stearic; its content was within the range 1.5-3.5\% for MAT7 and ZI1 oils, respectively (Table 1). For the other fatty acids: palmitoleic (C16:1) and arachidic (C20:0), although their contents changed from one olive oil to another, they were fairly small. According to statistical analysis, fatty acid compositional differences among the oils studied were significant, indicating a varietal effect on olive oil quality. These results are in agreement with the findings of other authors (Schiratti, 1999; Baccouri et al., 2007a; Baccouri et al., 2007b)

\subsubsection{Tocopherols}

Among the natural antioxidants present in virgin olive oil, tocopherols stand out because of their antioxidant activity and their important nutritional activity. Tocopherol analysis by HPLC revealed the presence of $\alpha, \beta, \gamma$ and $\delta$ tocopherols in all the olive oils studied. Total tocopherol content was significantly influenced by varietal factor (Table 2). It ranged from 310 (SB12) to $780 \mathrm{mg} / \mathrm{kg}$ (H3). As for total tocopherols, the amount of each tocopherol varied according to genotype (Figure 1). $\alpha$ tocopherol is the prominent one; changes in its content reflect the total tocopherol variation in all

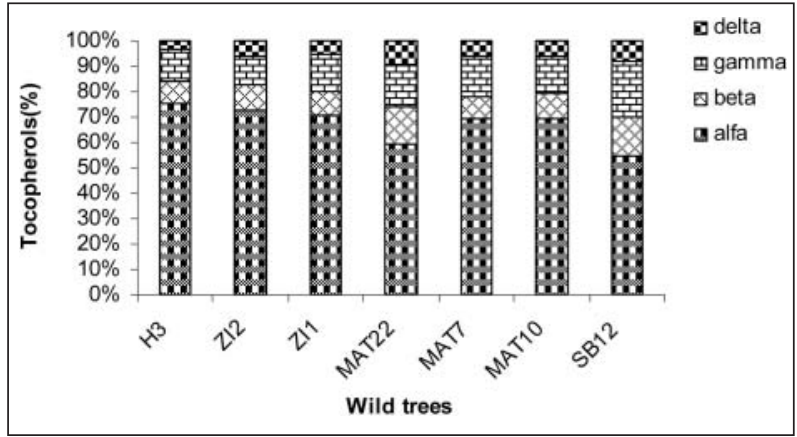

Figure 1

Portions of tocopherol compounds in virgin olive oils (in percent of total tocopherols).

the oils tested, whereas $\beta, \gamma$ and $\delta$ tocopherols are less represented and their concentrations do not exceed $100 \mathrm{mg} / \mathrm{kg}$.

As suggested by several authors, the tocopherol fraction in virgin olive oils consists mainly of $\alpha$ tocopherols; these substances exert both vitamin potency and antioxidant action. The olive oil samples studied have various $\alpha$-tocopherol amounts ranging from 170 (SB12) to $590 \mathrm{mg} / \mathrm{kg}$ (H3) (Table 2). These results are in agreement with those previously found suggesting that tocopherol content was highly variety-dependant (Baldioli et al., 1996). Duncan's test showed significant $(p<0.001)$ differences in the $\alpha$-tocopherol content among the studied cultivars. Usual values reported for good quality oils vary from 100 and $300 \mathrm{mg} / \mathrm{kg}$ (Baldioli et al., 1996). 


\subsubsection{Phenolic compounds}

The amount of phenolic compounds in EVOO is an important factor when evaluating its quality, given that the natural phenols improve its resistance to oxidation, and to a certain extent, are responsible for its sharp bitter taste (Gutierrez et al., 2001). The average content of total phenols in the samples analyzed was $293 \mathrm{mg} / \mathrm{kg}$, although a wide range of concentrations was observed, from 182 (MAT22) up to $430 \mathrm{mg} / \mathrm{kg}(\mathrm{H} 3)$. H3 oil had the highest contents of phenols and 0 -diphenols (435.3 and $217.6 \mathrm{mg} / \mathrm{kg}$, respectively), whereas MAT22 oil had the lowest (186 and $105 \mathrm{mg} / \mathrm{kg}$, respectively) (Table 3). Results show that the amounts of phenols and o-diphenols are highly variety-dependent. These results agree with those previously reported by (Baccouri et al., 2007a). They concluded that genetic factors influence olive oil quality and mainly phenolic composition.

The phenols are very important for the stability of olive oil (Gutierrez et al., 2001; Abaza et al., 2005). Moreover, the importance of phenolic compounds is related to the bitterness and astringency of olive oil (Kallithraka et al., 1997). This is consequently reflected in the organoleptic quality of olive oil (Visioli et al., 2000) as phenolic compounds contribute to virgin olive oil flavor and aroma (Angerosa et al., 2000), especially to its typical bitter taste (Gutierrez et al., 1992).

\subsubsection{Pigment contents}

The presence of natural pigments (chlorophylls and carotenoids) is relevant to the product with regards to technological characteristics and product stability (Boskou, 1996). Chlorophylls and carotenoids in oils studied ranged from 2.6 to $6.37 \mathrm{mg} / \mathrm{kg}$ and from 1 to $4.18 \mathrm{mg} / \mathrm{kg}$, respectively (Table 3). Significant differences among samples $(p<0.001)$ were observed with regard to pigment amounts.

\subsection{Effect of various compounds on virgin olive oil stability}

One of the most severe quality problems of virgin olive oil is its oxidative rancidity due to the oxidation of unsaturated fatty acids and subsequent formation of compounds that possess unpleasant taste and odor (Boskou, 1996).

The stability of the olive oils studied is highly influenced by varietal factor (Table 3). It ranged from 34 and $83.5 \mathrm{~h}$. The highest stability value was registered in $\mathrm{H} 3$ oil which can be explained by its richness in phenols and more exactly in o-diphenols (Table 3). As was found with respect to phenol contents, the oxidative stability of the seven oil samples is among the highest of Tunisian olive varieties, for instance Chemchali (22h), Chétoui (36h) and Oueslati (22h) (Abaza et al., 2005).

All the studied olive oils presented a high positive correlation between total phenols $\left(R^{2}=0.82\right)$ $\left(p<10^{-3}\right)$, o-diphenols $\left(R^{2}=0.88\right)\left(p<10^{-3}\right)$, and oxidative stability measured by Rancimat (Figure 2). However, total tocopherols and $\mathrm{C}_{18: 1} / \mathrm{C}_{18: 2}$ ratio, chlorophylls and carotenoids contents correlate poorly with oxidative stability $\left(R^{2}=0.27\right),\left(R^{2}=0.31\right)$, $\left(R^{2}=0.41\right)$ and $\left(R^{2}=0.49\right)\left(p<10^{-3}\right)$, respectively (Figure 2 ). These results agree with those recently reported about the levels of contribution of different olive oil constituents on stability; the contribution of phenolic and orthodiphenolic compounds being around $51 \%$, the composition of fatty acids $24 \%$, and in lower percentages, $\alpha$-tocopherol, carotenoids and chlorophylls. No effect, or very little, was shown by $\beta$ and $\gamma$-tocopherols (Aparicio et al., 1999). According to (Salvador et al., 1999), the total phenol contents do not completely explain the oxidative stability of Spanish olive oils. However, in the case of Italian olive oils, a fine correlation was established between the total phenol content and the peroxide value of products (Visioli et al., 2000).

It has been reported that the o-diphenols present in virgin olive oils are the most active antioxidants, whereas $\alpha$ tocopherol increases or decreases the Rancimat stability depending on the concentration of 0 -diphenols. A more detailed work of (Nissiotis and Tasioula-Margari 2002) brought out that hydroxytyrosol derivatives were the first antioxidants lost during oxidation and tyrosol derivatives decreased at the lowest rate, while $\alpha$-tocopherol showed an intermediate trend. These results explain the small contribution of tocopherol to the stability of the virgin olive oils studied.

Table 3

Stability parameters in virgin olive oils

\begin{tabular}{|c|c|c|c|c|c|c|c|}
\hline Stability parameters & $\mathrm{H3}$ & $\mathrm{ZI2}$ & ZI1 & MAT22 & MAT7 & MAT10 & SB12 \\
\hline Total Phenols (mg/kg) & $435.3^{a}$ & $355.0^{c}$ & $255.0^{\mathrm{e}}$ & $186.0^{f}$ & $325.0^{d}$ & $255.0^{e}$ & $390.0^{b}$ \\
\hline Total o-diphenols (mg/kg) & $217.6^{\mathrm{a}}$ & $176.3^{b}$ & $140.1^{\mathrm{c}}$ & $105.0^{d}$ & $147.5^{\mathrm{bc}}$ & $150.0^{\mathrm{bc}}$ & $165.0^{\mathrm{bc}}$ \\
\hline Total tocopherols (mg/kg) & $781.8^{\mathrm{a}}$ & $586.3^{b}$ & $518.8^{c}$ & $350.5^{d}$ & $523.2^{c}$ & $482.0^{c}$ & $309.5^{d}$ \\
\hline $\mathrm{C}_{18: 1} / \mathrm{C}_{18: 2}$ & $11.2^{\mathrm{a}}$ & $11.1^{\mathrm{a}}$ & $7.5^{\mathrm{b}}$ & $5.7^{\mathrm{c}}$ & $5.0^{c}$ & $6.4^{\mathrm{bc}}$ & $5.3^{c}$ \\
\hline Chlorophylls(mg/kg) & $5.1^{\mathrm{b}}$ & $6.4^{\mathrm{a}}$ & $2.6^{d}$ & $3.2^{\mathrm{cd}}$ & $3.4^{\mathrm{c}}$ & $3.4^{\mathrm{c}}$ & $3.0^{\text {cd }}$ \\
\hline Carotenoids(mg/kg) & $4.2^{\mathrm{a}}$ & $3.9^{b}$ & $1.0^{g}$ & $2.3^{c}$ & $1.2^{f}$ & $1.6^{\mathrm{e}}$ & $1.8^{d}$ \\
\hline Oxidative Stability (h) & $83.5^{\mathrm{a}}$ & $70.4^{b}$ & $40.3^{\mathrm{e}}$ & $34.1^{f}$ & $47.0^{d}$ & $57.1^{c}$ & $70.5^{b}$ \\
\hline
\end{tabular}

Significant differences in the same row are shown by different letters $(P \leq 0.001)$. 

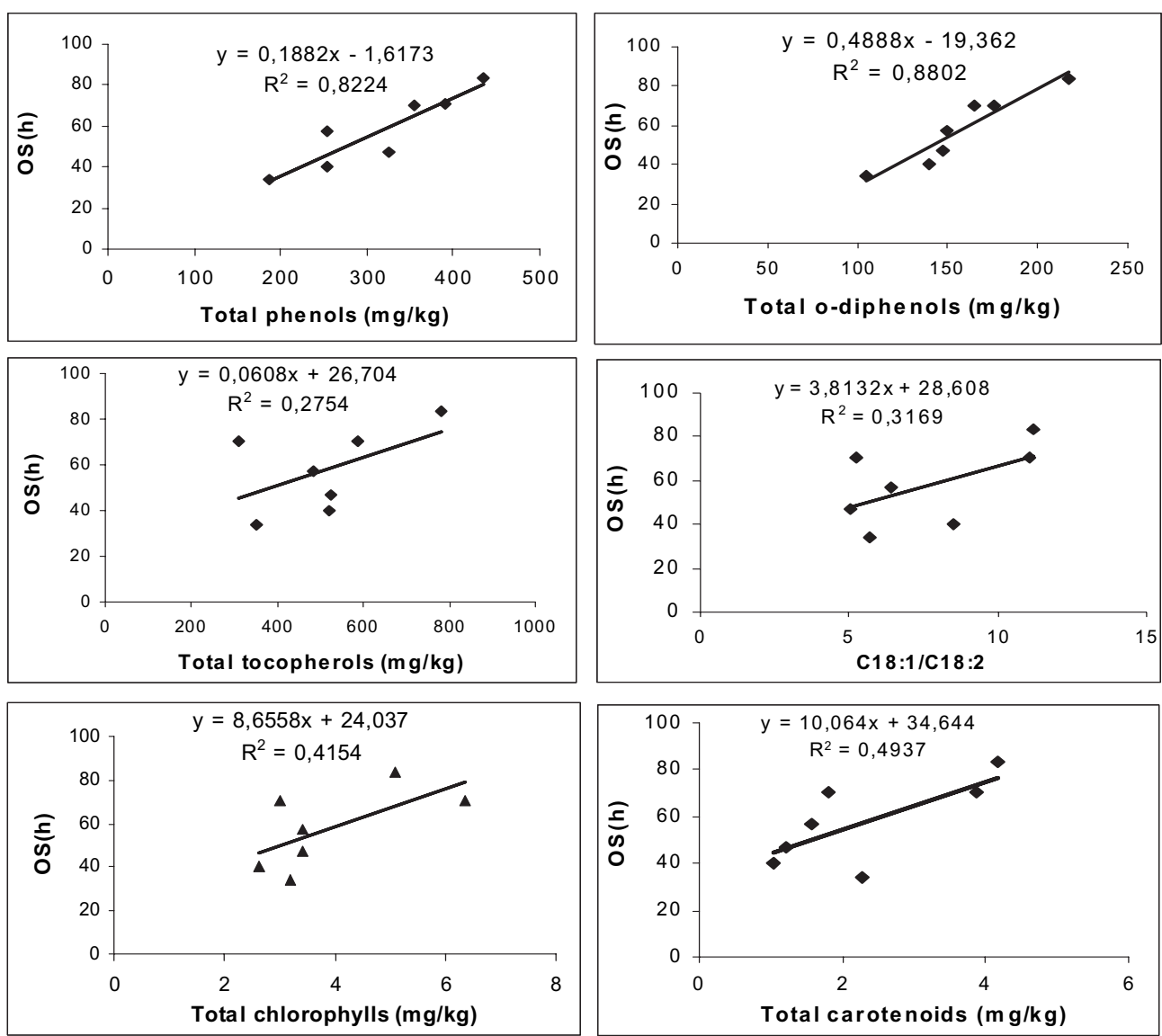

Figure 2

Correlation between different minor compounds and acidic composition with oxidative stability.

Virgin olive oil composition depends on a number of factors such as the interaction between the cultivar and the environment, cultivation techniques, fruit ripeness and oil extraction system (Abaza et al. 2005; Ben Temime et al., 2006; Baccouri et al., 2007c). The analysis of wild olive oils has shown that there were qualitative and quantitative differences among the chemical profiles of oils from the wild trees tested, in spite of having been cultivated under identical environmental conditions. As the harvesting period and extraction conditions were similar for all studied samples, the results indicate that the genetic factor related to the cultivar is one of the most important aspects of the chemical composition of olive oil.

\section{CONCLUSION}

The selection of new olive cultivars with a good oil quality among wild olives may be considered as a way to diversify our olive genetic resources and to select new cultivars for oil production under Tunisian conditions. Chemical characterization of extra virgin olive oil from the seven selected wild trees showed that all quality parameters fell within the limits established for the extra virgin olive oil category and also conform to the norm established by IOOC Regulations (IOOC, 2004). The wild olives studied produce oils with good quality characteristics in terms of natural antioxidants, oxidative stability and fatty acids. Further analyses, such as sterol composition and sensory analysis are necessary for a complete evaluation of these new cultivars.

\section{REFERENCES}

Abaza L, Taamalli W, Ben Temime S, Daoud D, Gutierrez F, Zarrouk M. 2005. Natural antioxidant composition as correlated to stability of some Tunisian virgin olive oils. Riv. Ital. Sostanze Grasse 82, 12-18.

Angerosa F, Mostallino R, Basti C, Vito R. 2000. Virgin olive oil odour notes: their relationships with volatile compounds from the lipoxygenase pathway and secoiridoid compounds. Food Chem. 68, 283-287.

Aparicio R, Roda L, Albi MA, Gutiérrez F. 1999. Effect of various compounds on virgin olive oil stability measured by Rancimat. J. Agric. Food Chem. 47, 4150-4155.

Baccouri B, Ben Temime S, Taamalli W, Daoud D M'sallem M, Zarrouk M. 2007a. Analytical characteristics of virgin olive oils from two new varieties obtained by controlled crossings on Meski variety. J. Food Lipids 14, 19-34.

Baccouri B, Ben Temime S, Campeol E, Cioni P, Daoud D, Zarrouk M. 2007b. Application of solid-phase 
microextraction to the analysis of volatile compounds in virgin olive oils from five new cultivars. Food Chem. 102, 850-856.

Baccouri B, Zarrouk W, Krichene D, Nouairi I, Ben youssef N, Daoud D, Zarrouk M. 2007C. Influence of fruit ripening and crop yield on chemical properties of virgin olive oils from seven selected oleasters (Olea Europaea L.). J. Agronomy 6 (3) 388-396.

Baldiolli M, Servili M, Perretti G, Montedero GF. 1996. Antioxidant activity of tocopherols and phenolic compounds of virgin olive oil. J. Am. Chem. Soc. 73, 1589-1593.

Ben Temime S, Baccouri B, Taamalli W, Abaza L, Daoud D, Zarrouk M. 2006. Location effects on Chétoui virgin olive oil stability. J. Food Biochem. 30, 659-670.

Boskou D. 1996. Olive Oil Quality in Boskou D. (Ed.) Olive Oil: Chemistry and Technology 101-120. AOCS Press, Champaign, IL, USA.

European Union Commission 1991. Regulation EEC/2568/91 on the characteristics of olive and olive pomace oils and their analytical methods. Official $\mathrm{J}$. Eur. Commu. L 248, 6-36.

Gutiérrez F. 1989. Determinacion de la estabilidade oxidativa de aceites de oliva virgenes: comparacion entre del método A.O.M. y el método Rancimat. Grasas Aceites 40, 1-5.

Gutiérrez F, Perdiguero S, Gutiérrez R, Olias JM. 1992. Evaluation of bitter taste in virgin olive oil. J. Am. Chem. Soc. 69, 394-395.

Gutiérrez F, Arnaud T., Garrido A. 2001. Contribution of polyphenols to the oxidative stability of virgin olive oil. J. Sci. Food Agric. 81, 1-8.

IUPAC - International Union of Pure and Applied Chemistry 1992. Determination of tocopherols and tocotrienols in vegetable fats by HPLC. Method 2.432 in Standard Methods for the Analysis of Oils, Fats and Derivatives. $7^{\text {th }}$ edition, Pergamon Press, Oxford, UK.

IOOC 2004. Annual statistics of International Olive Oil Council. Olive oil productions, available at: http://www.internationaloliveoil.org/downloads.
Kallithraka S, Bakker J, Clifford MN. 1997. Effect of pH astringency in model solutions of wines. J. Agric. Food Chem. 415, 2211-2216.

Nissiotis M, Tasioula-Margari M. 2002. Changes in antioxidant concentration of virgin olive oil during thermal oxidation. Food Chem. 77, 371-376.

Salvador MD, Aranda F, Fregapane G. 1999. Contribution of chemical components of Cornicabra virgin oils to oxidative stability. A study of three successive crop seasons. J. Am. Chem. Soc. 76, 427-432

Schiratti G. 1999. Presentacifin del estudio sobre la influencia de las variedades ambientales, agronfimicas y tecnolfigicas en las caracterssticas y niveles de los componentes menores del aceite de oliva virgen extra. Olivae 79, 38-40.

Sedgley M, Wirthensohn M. 2000. The Australian olive improvement program. Olivæ 83, 27-30.

Servilli M, Selvaggini R, Esposto S, Taticchi A, Montedoro GF, Morozzi G. 2004. Health and sensory properties of virgin olive oil hydrophilic phenols: Agronomic and technological aspects of production that affect their occurrence in the oil. J. Chrom. A. 1054, 113-127.

Trigui A. 1996. Improving the quantity and quality of olive production in Tunisia: unavoidable need and outlook for olive identification and breeding. Olivæ 61, 34-40.

Vazquez A, Janer del Valle C, Janer del Valle ML. 1973. Determinacion de los polifenoles totales en aceite de oliva. Grasas Aceites 24, 350-357.

Visioli F, Bellomo G, Galli C. 1998. Free radicalscavenging properties of olive oil polyphenols. Biochem. Biophy. Res. Commu. 247, 60-64.

Visioli F, Borsani L, Galli C. 2000. Diet and prevention of coronary heart disease: The potential role of phytochemicals. Cardio. Res. 47, 419-425.

Zohary D. 1994. The wild genetic resources of the cultivated olive. Acta Hort. Olive Growing II: 356, 62-65.

Recibido: $14 / 3 / 07$ Aceptado: 8/4/08 